\title{
Transit Subsidies in New York and Chicago: Local, State, and Federal Assistance in a Historical Context
}

\author{
Eric Petersen \\ Northwestern University
}

\begin{abstract}
$\overline{\text { Abstract }}$
Nearly all studies of the impact of government subsidies on the transit industry have excluded systems with rail transit. Thus, previous findings cannot simply be extended to transit systems in major metropolitan areas. As a preliminary step in addressing the issue of subsidies and large transit systems, this paper presents historical information on the financial state of the two largest transit systems in the U.S.Chicago's CTA and New York's NYCT. In addition, the subsidies to each system are broken down by level of government-federal, state, and local. The patterns for the two systems are quite different. The CTA remained in relative financial health longer than the NYCT. While the CTA's operating expenses have stabilized recently, its ridership levels (and revenues) have declined sharply. In terms of subsidies, the CTA receives most of these funds at the regional, not state or local, level. In contrast, NYCT's revenues were actually greater in 1995 than they were in 1954 (in constant dollars). However; its operating costs ballooned throughout the 1980s and only recently have been contained. Subsidies to the NYCT come almost equally from state and local sources.
\end{abstract}




\section{Introduction: Issues Surrounding Transit Subsidies}

This paper revisits the issue of mass transit subsidies.' Transit subsidies have been controversial from the inception of the Urban Mass Transportation Act of 1964. Since mass transit is generally viewed as an industry experiencing sharp declines in ridership, but also an industry that still serves essential social functions, people have lined up on both sides of the subsidy issue. Proponents of transit argue that preserving transit is a way of preserving the environment. They also stress relief from traffic congestion as a benefit of continued transit. In general, however, they pay more attention to equity rather than efficiency issues, and their focus is on social, rather than economic, benefits. Others are skeptical that the benefits of transit outweigh the costs of subsidization. In fact, many critics argue that subsidies (particularly operating subsidies) have themselves exacerbated the problem by reducing the productivity of transit systems.

If one does accept the rationales for subsidization, the next issue is whether these transit systems should be supported through capital grants or operating assistance or both. It is worth noting that government assistance for capital improvements has generally been more palatable to politicians, since capital grants are not perceived as open-ended. From the beginnings of federal aid to transit systems, economists warned that providing operating assistance would in essence be opening a Pandora's box, leading to the dissipation of these grants through "labor demands and by wasteful managerial practices" (Hilton 1984: 8). Indeed, operating subsidies were not authorized until 1974 and not without a great struggle on the part of transit advocates in Congress.

In addition, it is also necessary to distinguish between subsidies provided by the different levels of government-federal, state and local. While transit operating subsidies are usually discussed as if they were a purely federal responsibility, there is significant state and local support across the industry (38 percent of total revenues come from fares, 4.5 percent from non-transit sources, 31 percent from local government, 21.5 percent from state government, and only 5 percent from the federal government) (APTA 1996). However, there are wide variations in levels of local support. Smaller systems are typically more depen- 
dent upon federal aid than the aggregate figures suggest. Also, these figures do not include capital grants, where the federal government typically covers 80 percent of the costs.

Indeed, some people might agree that transit merited government support, but that it should be a local, not federal, responsibility. Many argue local government is better able to determine the wishes of the citizenry regarding transit support. The economists Shughart and Kimenyi (1991) believed that imposing more of the burden of financing capital expansion of transit systems on local authorities would result in more realistic projects, as well as more political accountability for transportation decisions. However, when looking at equity concerns associated with subsidies, Pucher and Hirschman (1981) calculated that using federal taxes was a more progressive method overall of financing rapid transit than using local taxes.

Perhaps the most daunting criticism is that transit subsidies have actually worsened the financial situation of mass transit agencies. For instance, Pucher, Markstedt, and Hirschman (1983) calculated that subsidies in and of themselves exacerbated cost increases in rapid transit, particularly labor costs. They criticized the fact that federal transit policy did not tie subsidies to specific goals or to realistic evaluations of transit needs. Shughart and Kimenyi found, like Pucher, Markstedt and Hirschman, that transit costs rose dramatically when federal subsidies were available. Lave (1991) takes a similarly negative view of federal transit subsidies.

This author contends that the subsidy issue is more complex than these studies have indicated. Indeed, the prior studies base their results on aggregate data, obscuring crucial distinctions between systems, such as size. In fact, much research on mass transit specifically excludes agencies that operate rail transit in order to focus on the typical transit agency. While there is some merit in this approach, it is irresponsible to then make sweeping claims about the impact of subsidies. In addition to industry-wide studies, one must analyze individual transit systems and their historical financial performance, particularly in the case of large multi-mode systems. Thus, this paper will present detailed information on 
the financial history, including subsidy levels, of the two largest transit systems in the United States: New York and Chicago. These transit properties are neither typical nor representative of the industry. However, New York City Transit (NYCT) and the Chicago Transit Authority (CTA) are an extremely significant part of the transit picture, together accounting for 27 percent of all transit trips in the U.S.

\section{Subsidies to Transit}

While it is tempting to view transit subsidies as something new, as early as the 19th century, various governmental bodies frequently ceded land for rightof-ways to transportation firms in order to persuade them to build in certain areas. Occasionally, additional land was provided to transportation firms with the intent that they would sell it to finance construction. Then, as now, transportation was viewed as necessary to stimulate regional development and other investment. Canals, railroads, mass transit lines and, of course, the interstate highway system were all built at least partly through government largesse. Even after these initial "capital grants," transportation firms have occasionally been given aid (either state or federal) to carry out specific projects. For instance, in Chicago, the WPA provided much of the funding for the construction of the State Street subway. Several other route extensions received federal funding prior to 1960. This support was not certainly unique to Chicago.

However, this aid had not been part of a systematic federal commitment to mass transit. Federal capital assistance had been somewhat sporadic and not a particularly reliable source of funding. The new era for transit subsidies came in 1964, with the passage of the Urban Mass Transportation Act. It is probably not a coincidence that this new commitment occurred at roughly the same time as the transit industry as a whole went into the red (Hilton 1974). The federal capital program grew rapidly; the cumulative total of federal capital grants from 1961 to 1996 exceeded $\$ 60$ billion.

Federal operating assistance was first authorized in 1974 and was extremely controversial at the time. However, it too became routine. As part of the political balancing act by transit supporters, operating assistance-originally allocated as Section 5 Grants-was split into Urbanized and Nonurbanized Area Formula 
Grants. As critics feared (and proponents hoped) would happen, operating assistance also increased dramatically throughout the 1970s and 1980s. By 1995, the cumulative total appropriations for urban operating assistance alone reached $\$ 16.5$ billion. The commitment to operating assistance has never been particularly strong, however, and federal operating subsidies are slated to be phased out by 1999. It is less clear what will happen to capital subsidies in the future, since transportation funding is supposed to be made somewhat more flexible under ISTEA. The states should be able to allocate their grants between transit and highways in the manner that best suits the needs of their citizens.

Clearly, we are in a new phase in the transit debate, where transit is again conceived of as largely a local responsibility. This will definitely lead to a greater reliance upon state and local sources of subsidy. In major cities with densities that make mass transit feasible, transit service will continue, though it may be scaled back. New York and Chicago, the two largest systems, certainly face a very different set of constraints than do smaller systems. They have farebox recovery rates that hover around 50 percent of operating expenses, but since their expenses are so large compared to the smaller systems, a large commitment from some government source is required to make up the difference.

\section{Financial Data}

The data were gathered primarily from Section 15 Reports or the Annual Reports of the two systems and occasionally supplemented by internal documents from the two systems. The transition from Annual Reports to Section 15 was not perfect. The data in the 1970s (and, indeed, the first few years of Section 15 data) frequently contain questionable values, which have to be checked or calculated from other information. In the Section 15 Reports, fare differentialsoccasionally categorized as revenues and sometimes as subsidies-have simply been included with operating assistance after 1982. This posed a serious dilemma in terms of maintaining consistency. In Figures 1 and 2, fare differentials have been incorporated with operating assistance for all years. In Figures 3 and 4, fare differentials are reported separately until 1982, at which point they are folded 
into the operating assistance from the appropriate governmental body. In effect, fare differentials have been added to state subsidy levels in Chicago and to local subsidies in New York. Finally, the history of New York City Transit makes it particularly difficult to ensure one is measuring the same things every year. Whenever possible, NYCT figures were kept separate from those of its subsidiary, the Manhattan and Bronx Surface Transit Operating Authority. However, these systems appear to have been consolidated in the mid 1980s (in the reports at least), perhaps as the result of another reorganization of the Metropolitan Transit Authority. In likelihood, this accounts for some portion of New York's increasing operating expenses after 1981.

\section{Financial History of the CTA}

The CTA was established in 1945 to take over the provision of transit from several bankrupt transit companies. It began providing service in 1947, after issuing bonds that were to be financed from passenger revenues. In 1952, CTA bought up the local bus company and became the only transit operator in Chicago. It was expected to break even, covering not only its operating expenses but also its debt service requirements (the cost of originally acquiring the cars and rail system). It even paid corporate taxes. CTA remained in financial health much longer than most transit operations, managing to cover operating expenses (though not always its debt service payments) until 1970 . After that, it quickly succumbed to the inflationary pressures that ruined other transit companies around the country.

CTA first received fare differentials in 1965 to make up the cost of reduced fares for students and seniors. It received general operating subsidies in 1971, but apparently did not receive federal operating assistance until 1978 . The state of Illinois has periodically provided grants to pay down much of CTA's debt (essentially making these capital grants). However, it did not want to get directly involved in a perpetual bail-out of the system. Instead, the Regional Transit Authority (RTA) was formed in 1974. The CTA, as well as the suburban bus and rail systems, were placed under the authority of the RTA. The legislature hoped that, by putting transit on a region-wide basis, the provision and funding of mass 


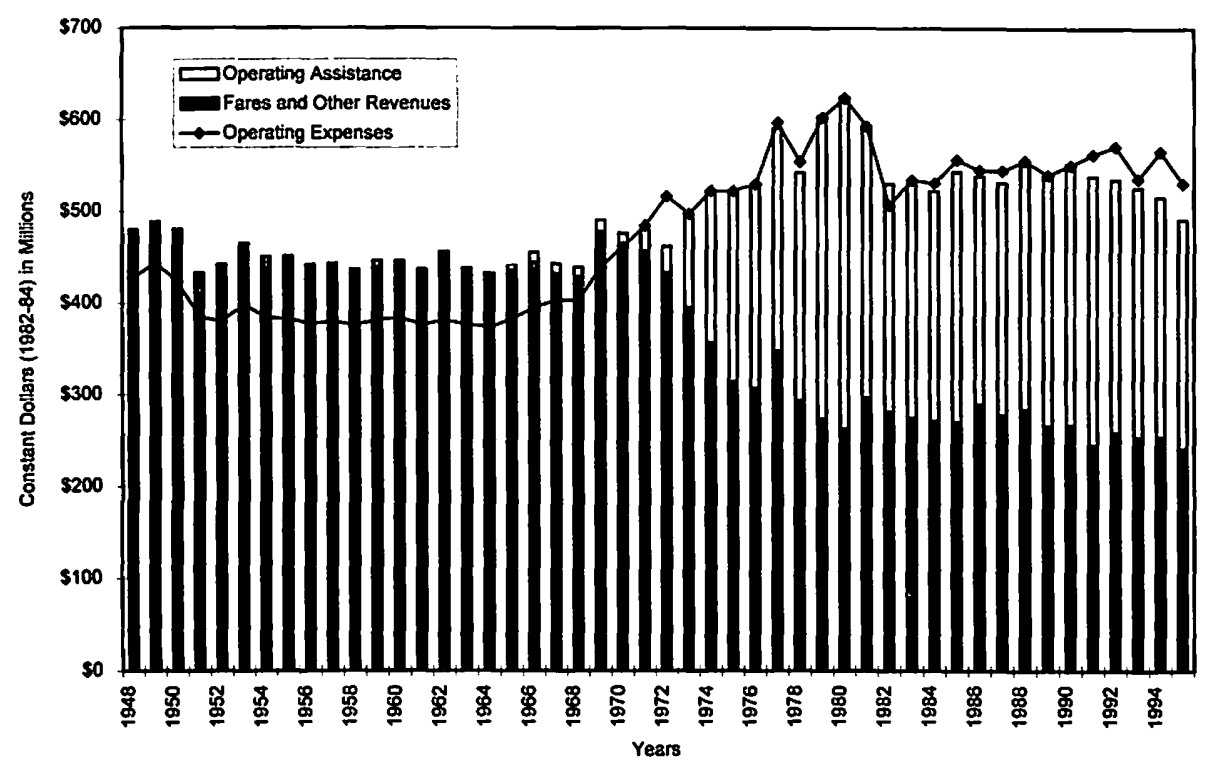

Figure 1. Chicago: Revenue and expenses.

transportation would be stabilized. Even after the creation of the RTA, however, transit operating deficits continued to increase. At several points in the early 1980s, it appeared that CTA would not be able to meet its payroll, and rumors surfaced that CTA would be shut down. In response to this ongoing financial crisis, the RTA itself was reorganized in 1983 (Krambles 1993).

Although the state of Illinois essentially takes a hand-off approach to transit finance, it did set up a sales tax in the six-county Chicago metropolitan region which directly benefits the RTA. In addition, the state provides an additional 25 percent over and above the total revenue collected through the sales tax. These moneys are then allocated to the RTA's service boards (CTA, Metra, and PACE). Thus, the state does provide significant support to mass transit, but in a somewhat indirect fashion. Furthermore, in recent years, the state has not passed the bonds that would have provided matching funds for federal capital grants, adding to the impression that transit in Chicago is a local concern. 


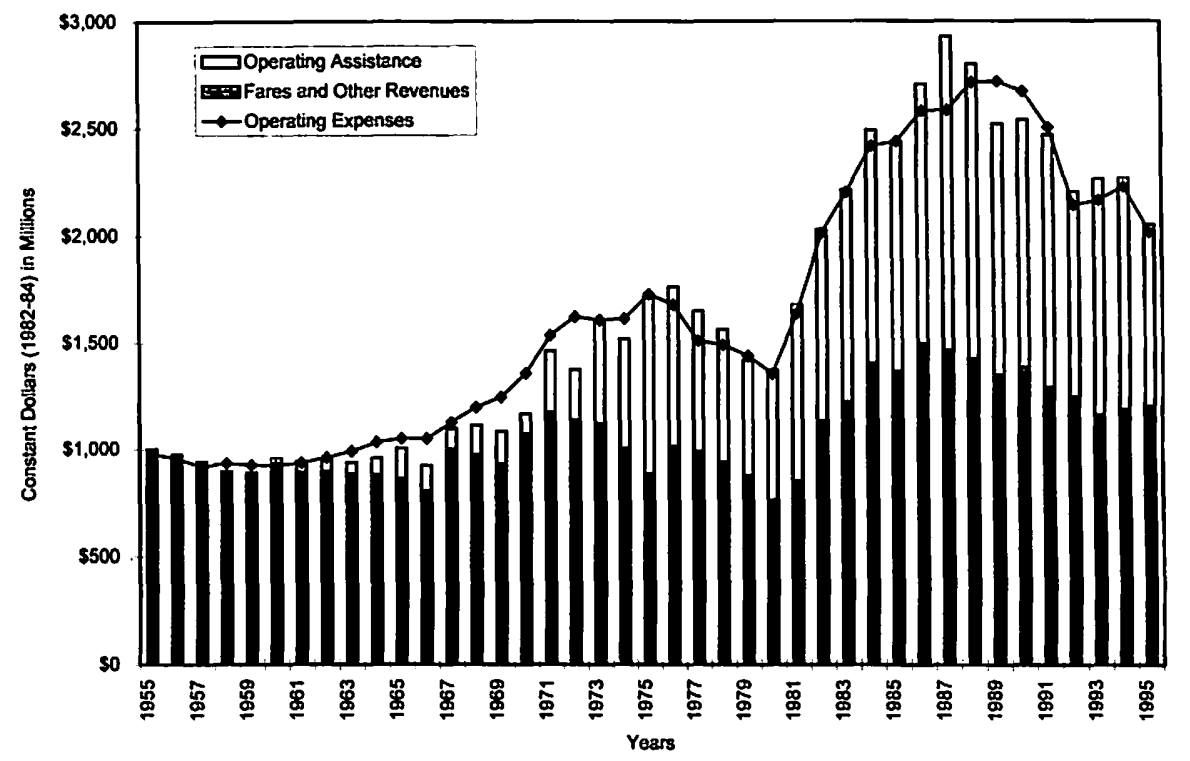

Figure 2. New York: Revenue and expenses.

\section{Financial History of the NYCT}

In contrast to Chicago's relative health, New York City's subways have been in crisis longer. All three subway systems (the private BMT and IRT and, later, the city-run IND) were in severe financial crisis from the 1920s onward. They were municipalized in 1940 under Fiorello La Guardia, who assumed that major efficiencies of scale would be achieved by combining the systems (Hood 1993). Just as in Chicago, NYCT was to be run as a business, with no subsidies provided. Unfortunately, it did not take long for financial problems to resurface, certainly, in part, because City officials still would not allow the fare to rise above a nickel.

New York State reorganized the City's Board of Transportation into the New York City Transit Authority in 1953 (Danielson and Doig 1982). However, because the Authority had no taxing power, this reorganization was of limited use. The State, under Governor Nelson Rockefeller, came up with additional funding for mass transit, including funds for commuter railroads. While this meant the 


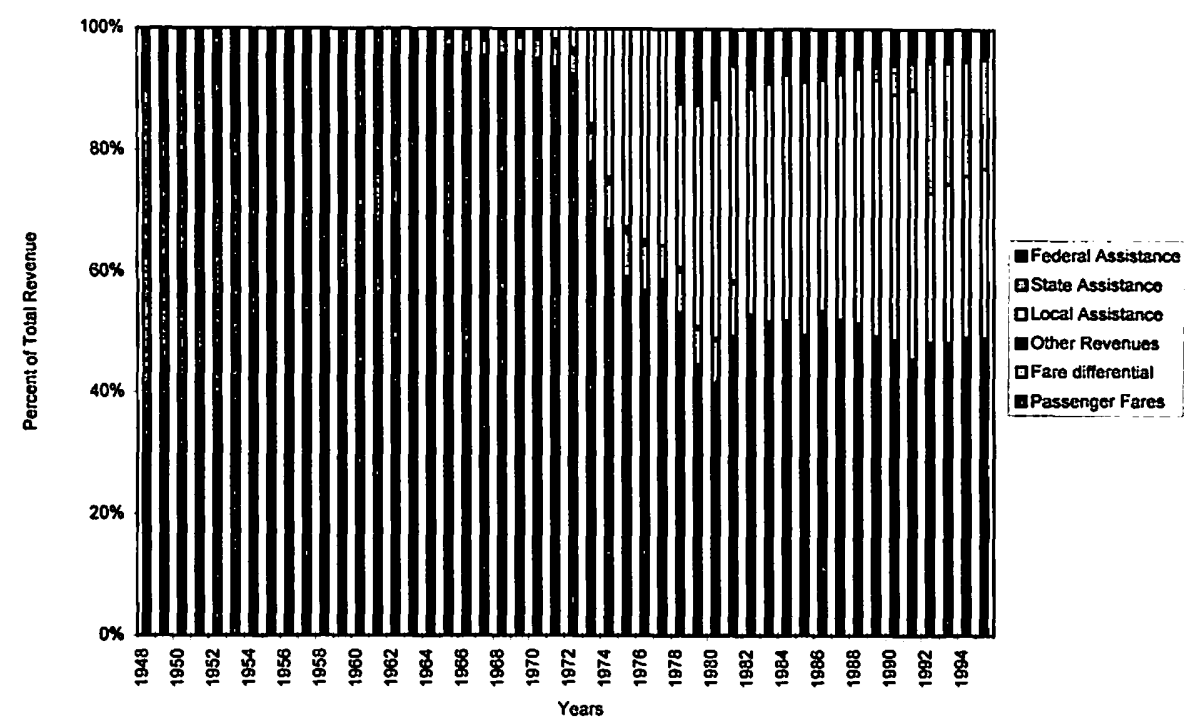

Figure 3. Chicago: Revenue sources.

State was providing some subsidies to New York transit, this was not a stable source of funds. It should be noted that the State (along with the City) has been very involved in New York's transit problems for some time. There is a much closer relationship between the State and the City, though this has been strained from time to time, particularly in recent years. Thus, it is not surprising to find that the proportion of State aid to New York's transit system has consistently been substantial (generally 20 percent).

In 1968, the Metropolitan Transportation Authority (MTA) was created through the merger of NYCT and the Triborough Authority (Danielson and Doig 1982). The Triborough Authority was in much better financial shape and thus was able subsidize transit service. Transit was tied into a regional source of funding for the first time. Furthermore, transportation planning was rationalized and coordinated; problems could be addressed at once, rather than in a piecemeal fashion (Danielson and Doig 1982). 


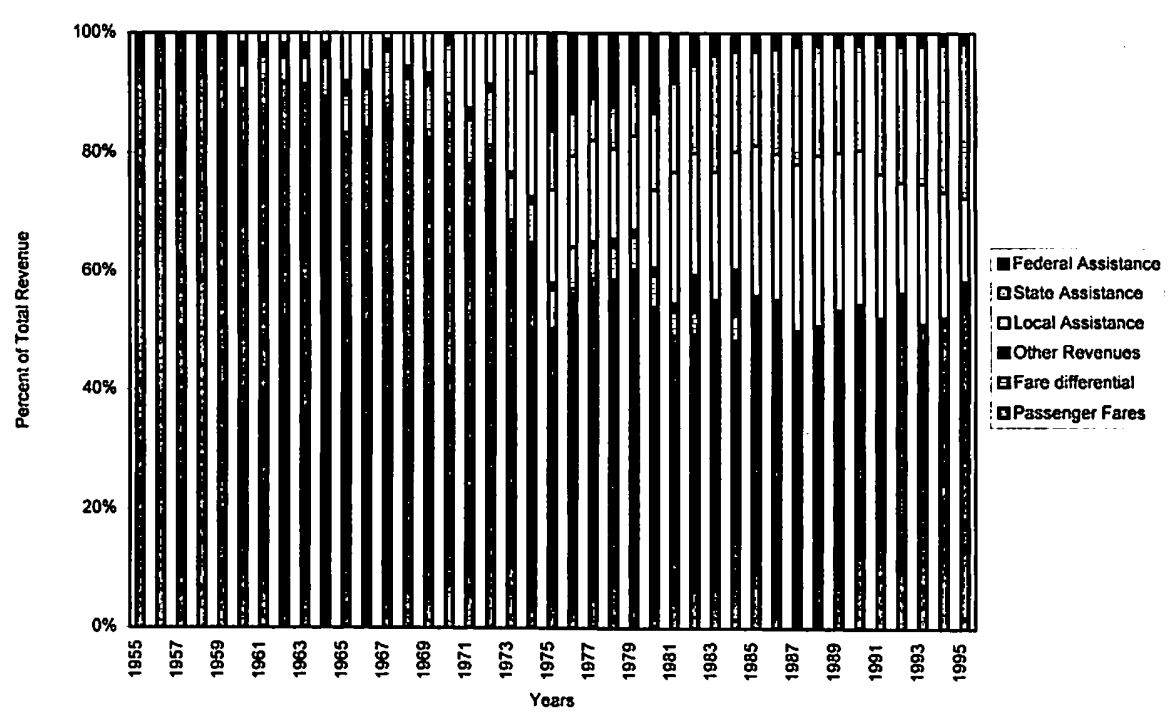

Figure 4. New York: Revenue sources.

Unfortunately, the problems were greater than had originally been imagined. By 1970, the subways were running a deficit of $\$ 120$ million (Danielson and Doig 1982). Governor Rockefeller did not approve of federal-local activities that bypassed the states and was wary of approaching Washington (Danielson 1965). However, City officials felt no such hesitation, and they called upon the federal government for emergency operating assistance (Danielson and Doig 1982). New York received federal operating assistance in 1975 and in every subsequent year. The emergency federal funding became a permanent state of affairs, as many expected it would, though the federal proportion of total revenues has declined greatly over the years.

\section{Analysis of the Systems' Financial Situations}

This analysis of deficits and subsidy levels goes back to the 1947 creation of CTA and the 1953 restructuring of NYCT. ${ }^{2}$ Given how the transit systems have had such different relationships with their respective states, it is hardly 
surprising that the patterns of subsidies for the two systems are very different. CTA has relied much more heavily upon local (or at least regional) financing. It is only in the last few years that State assistance has shown up in their reports, though the true level of State assistance is clearly somewhat higher than in the early Section 15 reports. CTA's reliance on federal funding hovers around 5 percent, which is the same as the industry average.

New York relied on local funding earlier (as far back as 1960). It had received state assistance by 1974 (which, over time, increased to roughly 20 percent of its total revenues) and federal assistance in 1975. After relying very heavily on emergency operating funds from the federal government for several years, NYCT's dependence dropped. Currently, federal assistance makes up only 2 percent of its overall operating revenues. Of course, it is worth noting that, due to its immense size, New York still receives roughly 40 percent more assistance in gross terms than does CTA. (Another way to put the two systems into perspective is to note that New York's state subsidies alone are often larger than Chicago's combined operating revenues.)

It is true that CTA remained in relative financial health for much longer than NYCT. Indeed, CTA was able to meet its operating expenses through passenger revenue until 1971. In the last 20 years, CTA has faced sharp declines in operating revenues in constant dollars, though the operating expenses seem to have more or less stabilized. In contrast, NYCT now has greater revenues than it did in 1954 (in constant dollars). However, its operating costs ballooned throughout the 1980s. While New York has certainly had trouble with its expenses, it appears that it has made dramatic improvements since 1989. By looking at the charts of revenues and expenses, one can identify many of the points at which the systems got into deep trouble. It appears that both systems faced increasing costs in the late 1960s. What might explain such a situation? This period follows the introduction of federal capital subsidies but is before federal operating subsidies were authorized in 1974. If it is true that labor costs were driving the cost increases, then this must have occurred even without the introduction of operating subsidies (or at least federal operating subsidies). One plausible explanation 
is that, in Chicago at least, several route extensions were finally opened up in the late 1960s, including the Eisenhower, Dan Ryan, and Kennedy extensions (Krambles 1993). Of course, these extensions were made possible by the newly available federal capital grants.

However, these years were also extremely bad ones for CTA's ridership. Annual ridership decreased from 510.5 million in 1967 to 457.8 million in 1968. There was an additional 34 million passenger drop the next year (perhaps in part due to a fare increase). The combination of CTA's expansion of its service area with such a sharp drop in its ridership was disastrous. It is hardly surprising that CTA was relying upon general operating assistance by 1971 .

Yet the subsidies were never able to stop the disappearance of CTA's passengers, however. Another large drop occurred between 1980 and 1982, when more than 10 percent of the overall passengers and 15 percent of rail passengers switched to other modes of transportation. Again, it is quite likely that a 50 percent increase in the base fare (from $\$ .60$ to $\$ .90$ ) triggered at least part of this rider flight. To look at the figures in a more positive light, it would be worth investigating how CTA managed to cut its expenses so dramatically in 1980 and again in 1981. The financial reports indicate that there was a savings of $\$ 35$ million in labor costs and associated benefits. If this was a true savings (and not accounting wizardry), one would want to see if it could be replicated. CTA's costs have remained relatively stable since 1985 , so perhaps more attention can now be given to the revenue side.

With respect to the situation in New York, it is clear that their greatest problems were with the cost side and not necessarily with the passenger revenues. Operating costs increased sharply between 1966 (perhaps not coincidentally the year of a major transit strike) and 1975. Suddenly, operating costs decreased sharply. This may have been due to across-the-board service cutbacks and maintenance deferral. In 1980, costs shot up even higher. On the other hand, revenues also made a fairly dramatic recovery. Perhaps these figures reflect the stewardship of David Gunn, who made major improvements during his tenure at the Transit Authority. The costs again decreased from 1989 to 1992, though they 
crept up again in recent years. Operating costs appear to have dropped again in 1995. The reasons for this are unclear.

New York has always had the highest transit share of any city in the U.S., largely due to Manhattan's very high population density and unique geographical features. Transit is essential to New York, and New Yorkers have never been able to completely escape using the subway, even at the times they may have wanted to. New York's transit use patterns have essentially been cyclical, with ridership recovering from periodic declines. While ridership will almost certainly never reach the level of the late 1950s and early 1960s (with 1.8 billion annual passengers), 1995 was the best in several years (with 1.55 billion passengers taking transit). Actually, 1971, 1980, and 1989 were also peak years, much like 1995 was. In each of these years, transit ridership was roughly 1.5 billion passengers. The lowest years occurred in the late 1970s. In 1976 and 1978, ridership was down to roughly 1.3 billion passengers annually. The fact that so many New Yorkers still take transit (in contrast to the severe fall-off in transit use in Chicago) means that fare revenues have remained high. This has been one bright spot in New York's financial picture. In those years that the MTA was able to control costs (such as 1990 and 1991), the operating deficit was significantly reduced.

\section{Expenditure of Operating Funds}

The way that these systems disperse their operating funds is reasonably similar. For both systems, labor is the primary expense. Both systems spend roughly 80 percent on labor, including all salaries and fringe benefits. This has been the case since $1980 .{ }^{3}$ While labor costs were somewhat lower prior to the 1960s, labor has always been the single greatest expense for transit systems. Materials and supplies are generally the next major expense; over the last 17 years, they have averaged 7.5 percent of total operating costs for New York and 10 percent for Chicago. (Of course, the very expensive materials needed for rail reconstruction are accounted for as a capital expense.) Utilities have accounted for 5 percent of New York's operating costs, on average; they have made up 
roughly 4 percent of Chicago's costs. Finally, on average, fuel accounts for only 1 percent of New York's costs, while it accounts for 3 percent of Chicago's costs. This is less surprising when one considers that New York is heavily oriented towards rail transit.

When looking at operating costs by function (and not object class), it is somewhat startling to note that maintenance has been fairly stable. Maintenance is nearly always cut back when budgetary shortfalls occur. Over the last 17 years, Chicago has spent 12.1 percent of its operating funds on non-vehicle maintenance. This amount has been as high as 14.1 percent but never below 10.1 percent (even in 1981, when the system was facing an especially bad fiscal crisis).

In Table 1, in addition to the average for the last 17 years, the average of the last 4 years of available data was included. The reason for this is that the accounting categories for what constituted vehicle operations and general administration was changed. New York dropped from spending fully 30 percent of its operating funds on administration to 11 percent the following year. In order to truly compare the two systems on administrative costs, the last four years seem more relevant. Interestingly, both systems spend almost identical proportions on vehicle operations ( 50.8 percent and 50.6 percent). Looking at the last four years only, Chicago spends more on general administration. In general, Chicago also spends a slightly higher proportion of its budget

\begin{tabular}{|lrr|}
\hline \multicolumn{3}{|c|}{ Table 1 } \\
Proportion of Total Operating Costs \\
\hline & $\begin{array}{r}\text { Average } \\
\text { 1979-95 } \\
\text { (\%) }\end{array}$ & $\begin{array}{r}\text { Average } \\
\text { 1992-95 } \\
\text { (\%) }\end{array}$ \\
\hline New York & & \\
Vehicle Operations & 40.3 & 50.8 \\
Vehicle Maintenance & 19.3 & 17.4 \\
Non-Vehicle Maintenance & 17.2 & 19.3 \\
General Administration & 23.1 & 12.1 \\
& & \\
Chicago & & \\
Vehicle Operations & 51.0 & 50.6 \\
Vehicle Maintenance & 20.1 & 20.0 \\
Non-Vehicle Maintenance & 12.1 & 13.2 \\
General Administration & 15.5 & 13.5 \\
\hline
\end{tabular}


on vehicle maintenance and less on non-vehicle maintenance than does New York. Again, this is consistent with the CTA being a bus-oriented agency.

\section{Other Financial Issues}

This paper has largely focused on operating subsidies, in part because they are particularly controversial and the funding patterns are so different among various systems. ${ }^{4}$ With capital grants, federal funding is by far the most important source across all systems. However, the distinction between operating and capital funding is somewhat arbitrary. While the distinction certainly has real consequences for transit systems, funding categories can and do shift, generally for political reasons.

Often higher levels of government change the rules for transit agencies. This may mean that an "inviolable" transportation trust fund is tapped into during a severe fiscal crisis. Similarly, promised funds may not be available. On the other hand, a state or federal agency may make funding more flexible, so that transit agencies can allocate resources according to their needs. This is the intent of ISTEA.

However, not all funds can be "flexed" between categories. Both CTA and NYCT have deferred some kinds of maintenance in favor of shorter term operating functions. This is one way of moving capital funds over to cover operating expenses. Programmed federal funds, especially for "New Starts" cannot be moved about so cavalierly. Unfortunately, even after the implementation of ISTEA, the funding structure for transit subsidies continues to demonstrate a bias in favor of system expansion rather than system maintenance. Given that operating subsidies are being zeroed out, transit operators are forced to devise strategies for obtaining capital funding from Washington. In essence, they are looking for a "capital fix." One result of this is that transit operators defer maintenance until a portion of the system has to be reconstructed-and thus is eligible for federal support. This is basically what occurred on Chicago's Green Line, which recently reopened. The strategy is a perfectly rational one, given that transit systems operate in a resource-constrained environment. Unfortunately, the cost of 
reconstruction is almost always much higher than what was "saved" by deferring maintenance. Indeed, this strategy is not limited to transit operators. Most state highway departments are forced to adopt the same tactics, given the capital bias in federal funding (Sanders 1995). Making transit funds more "fungible" would help avoid these inefficiencies. However, given the chronic shortfall in operating funds, transit systems are likely to divert capital funds to operations when possible. This is a historic pattern, going back to the original owners of private transit systems. Thus, a complete analysis of transit funding would have to look at the amounts of capital funding channeled to operations, though determining the exact amounts is very difficult, given the nature of the financial portion of older annual reports. At present, this information has not been compiled.

\section{Points for Further Research}

Further research into transit subsidies and productivity is necessary before one could conclusively demonstrate that it was the subsidies (either operating or capital) that accelerated the financial crises of the transit industry in the 1970s and 1980s. In order to fully test this hypothesis, one would first need to collect several other performance measures, including passenger miles, revenue miles, and number of employees. In addition, one would need to determine the metropolitan population, number of private automobiles (to measure the competition), strike activity, and the price of labor, fuel, and capital over these years. Of course, one would also need to determine capital funding (and diversions of capital funding) as well. This extension of the research is currently under way. Still, the historical financial information by itself is crucial for determining the major fluctuations in the financial situation of either system, which, in turn, will allow transportation experts to focus their attention most intently upon these crucial moments.

\section{Endnotes}

1 This is a revised version of a paper presented in Chicago at the May 1997 Metropolitan Conference on Public Transportation Research. The author wishes to thank Prof. Ian Savage and two anonymous readers for comments on this paper, as well as the 
staff of Northwestern's Transportation Library for their assistance in the data collection process.

${ }^{2}$ Since the first year of operation for each system was only a partial year, this data was not included in any charts.

${ }^{3}$ All information in this section comes from Section 15 Reports and thus only covers FY 1979 to 1995.

${ }^{4}$ This section, along with additional material on operating expenses, was added on the recommendation of an anonymous reviewer.

\section{Acknowledgments}

This is a revised version of a paper presented in Chicago at the May 1997 Metropolitan Conference on Public Transportation Research. The author wishes to thank Prof. Ian Savage and two anonymous reviewers for comments on this paper, as well as the staff of Northwestern's Transportation Library for their assistance in the data collection process.

\section{References}

Altshuler, Alan A. (with James P. Womack and John R. Pucher). 1979. The Urban

Transportation System: Politics and Policy Innovation. Cambridge, MA: MIT Press.

APTA. 1996. APTA Transit Fact Book. Washington D.C.: APTA.

Chicago Transit Authority. Annual Reports.

Danielson, Michael N. 1965. Federal-Metropolitan Politics and the Commuter Crisis.

New York: Columbia University Press.

Danielson, Michael N., and Jameson W. Doig. 1982. New York: The Politics of Urban Regional Development. Berkeley, CA: University of California Press.

Frankena, Mark W. 1982. The Justification for Transit Subsidies. Chapter 5 in Urban Transportation Financing: Theory and Policy in Ontario. Toronto, University of Toronto Press.

Hilton, George W. 1974. Federal Transit Subsidies: The Urban Mass Transportation Assistance Program. Washington, D.C.: American Enterprise Institute for Public Policy Research.

Hood, Clifton. 1993. 722 Miles: The Building of the Subways and How They Transformed New York. New York: Simon \& Schuster. 
Jones, David W., Jr. 1985. Urban Transit Policy: An Economic and Political History. Englewood Cliffs, NJ: Prentice-Hall, Inc.

Krambles, George, and Art Peterson. 1993. CTA at 45: Recollections of the First 45 years of the Chicago Transit Authority. Oak Park, IL: George Krambles Transit Scholarship Fund.

Lave, Charles. 1991. Federal Subsidies and the Ruinous Decline in Transit Productivity: It Wasn't Supposed to Turn Out Like This. Berkeley, CA: Transportation Center, University of California.

Metropolitan Transit Authority. Annual Reports.

New York City Transit Authority. Annual Reports.

Pucher, John, and Ira Hirschman. 1981. Distribution of the Tax Burden of Transit Subsidies in the United States, Public Policy 29 (3): 341-367.

Pucher, John. 1983. Distribution of Federal Transportation Subsidies: Cities, States, and Regions, Urban Affairs Quarterly 19 (2): 191-216.

Pucher, John, Anders Markstedt, and Ira Hirschman. 1983. Impacts of Subsidies on the Costs of Urban Public Transport, Journal of Transport Economics and Policy 17 (2): 155-76.

Regional Transit Authority. 1996. 1997 Annual Budget and Five-Year Program. Chicago: RTA.

Sanders, Heywood T. 1995. Public Works and Public Dollars: Federal Infrastructure Aid and Local Investment Policy, in Building the Public City: The Politics, Governace, and Finance of Public Infrastructure, Urban Affairs Annual Review 43, David C. Perry, ed., Thousand Oaks, CA: SAGE Publications.

Shughart, William F., and Mwangi S. Kimenyi. 1991. Public Choice, Public Subsidies, and Public Transit, Washington, DC: Urban Mass Transportation Administration.

U.S. Conference of Mayors. 1979. Transit Financing: An Overview of the National Transit Financing Picture in Terms of Federal and State Funding Levels, Fare Structures and Local Revenue Sources, Washington D.C: U.S. Department of Transportation.

Wachs, M. 1985. The Politicization of Transit Subsidy Policy in America, in Transportation and Mobility in an Era of Transition, Gijsbertus R.M. Jansen, et al., eds., Amsterdam: Elsevier Science Publishers. 
Womack, James P., and Alan A. Altshuler. 1979. An Examination of the Transit Funding Process at the Local Level. Cambridge, MA: Center for Transportation Studies.

\section{About the Author}

Eric Petersen is a graduate student in the Transportation Center at Northwestern University, as well as in the Sociology Department. In addition to studying mass transit subsidies, he has written on reverse commuting programs, the group dynamics of international travelers, and the politics of urban transportation planning. 